\title{
Coronavírus e saúde bucal: como cuidar dos meus dentes?
}

Rogerio Cardoso (1)

\section{ARTIGO ORIGINAL}

\section{Resumo}

Todos nós temos monitorado as notícias mais recentes sobre a COVID-19 e o impacto que continua a ter sobre nossas comunidades, bairros e famílias. Entendemos que este é um momento estressante. Talvez, você não consiga visitar seu dentista para limpezas, restaurações e coroas de rotina, ou pode estar preocupado em procurar ajuda se tiver dor de dente intensa, inchaço ou outra emergência odontológica. Para ajudar a esclarecer esses pontos e certificar que você tenha respostas confiáveis, criamos uma lista com as dúvidas mais frequentes para ajudá-lo a cuidar da sua saúde bucal durante esse período.

Palavras Cheave: Covid 19, Odontologia, Sintomas, Saúde bucal. 


\title{
Coronavirus and oral health: how to take care of my teeth?
}

\begin{abstract}
We have all been monitoring the latest news about COVID-19 and the impact it continues to have on our communities, neighborhoods and families. We understand that this is a stressful time. You may not be able to visit your dentist for routine cleaning, restorations and crowns, or you may be concerned about seeking help if you have severe toothache, swelling or another dental emergency. To help clarify these points and make sure you have reliable answers, we've created a list of the most frequently asked questions to help you take care of your oral health during this time.
\end{abstract}

Key words: Covid 19, Dentistry, Symptoms, Oral health.

Instituição afiliada: 1- Discente de Implantodontia no GOE/Uniavan.

Dados da publicação: Artigo recebido em 10 de Fevereiro, revisado em 15 de Fevereiro, aceito para publicação em 20 de Fevereiro e publicado em 28 de Fevereiro.

DOI: https://doi.org/10.36557/2674-8169.2021v3n2p24-30

Rogerio Cardoso impcard@gmail.com

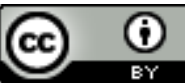

This work is licensed under a Creative Commons Attribution 4.0 International

License. 


\section{Perguntas Frequentes}

\section{Uma boa higiene bucal pode prevenir a COVID-19?}

Embora ainda estejamos aprendendo mais sobre a COVID-19 e sua propagação, atualmente não há evidências indicando que a COVID-19 possa ser prevenido com uma boa higiene bucal. No entanto, sabemos que ter uma boa higiene bucal pode reduzir doenças dentárias como cáries e periodontite, e que manter uma boa saúde bucal tem um impacto positivo na sua saúde como um todo.

É importante observar que vírus respiratórios, como o que causa a COVID-19, se iniciam e se espalham na cavidade nasal, na cavidade oral e na garganta. Tocar os olhos também pode ser uma fonte de transmissão. Praticar uma boa higiene bucal não afetará a transmissão para esses locais.

O Centro de Controle e Preveção de Doenças dos EUA (CDC, na sigla em inglês) tem uma série de recomendações sobre como proteger a si e aos outros da COVID-19. No entanto, essas recomendações não incluem práticas de higiene bucal como medida preventiva. Se você e sua família estão ficando em casa para ajudar a prevenir a propagação, além das medidas recomendadas pelo CDC, aproveite a oportunidade para incentivar as crianças a desenvolverem bons hábitos de higiene bucal.

\section{Devo trocar ou desinfetar minha escova de dentes, caso tenha tido COVID-19?}

Limpar sua escova após cada uso é uma ótima prática. Se você está se recuperando de uma doença, inclusive se seu teste deu positivo ou se você acredita ter tido COVID-19, é recomendável trocar sua escova de dentes. Se você não puder trocála, considere desinfetar a cabeça da escova para ajudar a reduzir a quantidade bactérias.

\section{De quais sintomas orais da COVID-19 devo estar ciente?}

Segundo o CDC, pessoas com COVID-19 relataram uma ampla gama de sintomas 2 a 14 dias após a exposição ao vírus, incluindo tosse, dores e desconfortos, febre e perda de paladar e olfato. Atualmente, é difícil afirmar que tipo de manifestações orais resultarão à medida que a doença e os sintomas continuam a evoluir. Além disso, muitos sintomas orais podem ser causados por outras doenças ou alergias. Se você acha que foi exposto à COVID-19, entre em contato com seu médico.

\section{0 que os dentistas estão fazendo para prevenir a COVID-19?}

O CDC recomenda que "os serviços sejam limitados a visitas de emergência somente durante esse período da pandemia. Essas ações ajudam a equipe e os pacientes a se manterem seguros, preservam equipamentos de proteção individual e suprimentos de assistência ao paciente e expandem a capacidade disponível do sistema de saúde." Se o seu dentista determinar que você precisa de uma consulta 
pessoal, siga as instruções do dentista para reduzir o risco de transmissão.

\section{Devo ir ao dentista durante o surto da COVID-19?}

Não, apenas vá ao dentista se for uma emergência. Buscando dicas de cuidados odontológicos relacionados ao coronavírus? Você pode ligar para o seu dentista para que ele o ajude a avaliar se a sua doença dentária se enquadra nas categorias de urgência ou emergência. Mesmo se o consultório do seu dentista estiver fechado, pode haver um número de emergência ou instruções de contato disponíveis na mensagem do correio de voz. Abaixo, seguem algumas dicas sobre como lidar com doenças dentárias não emergenciais para melhor auxiliá-lo a cuidar dos seus dentes com segurança durante a pandemia do coronavírus.

\section{Lidando com doenças dentárias não emergenciais}

Os bráquetes e fios dos aparelhos tradicionais são frágeis e podem se quebrar por vários motivos. Fios e bráquetes quebrados podem ser cortantes e incômodos, mas no geral não caracterizam uma emergência. Entre em contato com seu ortodontista ou dentista geral, que podem fornecer alguns conselhos para um tratamento simples em casa. Isso pode incluir algumas dicas para lidar com um bráquete quebrado ou com um fio quebrado em casa.

Mais 600 medicamentos, como diuréticos e anti-histamínicos, deficiências nutricionais ou alterações hormonais podem causar boca seca. Mantenha a boca úmida, bebendo bastante água e mascando chiclete sem açúcar. O uso de um substituto salivar também pode combater a secura e ajudar a manter a boca mais agradável e aliviar os sintomas. Lembre-se de que os substitutos salivares não são aprovados para benefício terapêutico, a menos que contenham fluoreto.

Ingerir uma quantidade excessiva de bebidas ácidas como refrigerantes e outras bebidas gaseificadas, escovar exageradamente a língua e a gengiva, e usar enxaguante bucal em excesso pode irritar os tecidos bucais. Tente reduzir o consumo de bebidas ácidas. Fale com o seu dentista sobre seus hábitos de higiene bucal e como minimizar irritações.

Sua rotina diária de higiene bucal deve incluir escovação duas vezes ao dia e uso do fio dental uma vez ao dia. Se sua gengiva sangra ao passar o fio dental, isso pode ser um sinal de inflamação e doenças gengivais, como gengivite ou periodontite. Usar um enxaguante bucal pode ajudar a diminuir as bactérias, ou faça bochecho com água morna e sal se sua gengiva estiver irritada. Se você tiver dor ou sangramento contínuo, entre em contato com o seu dentista.

Sangramento na gengiva pode ser um sinal importante de gengivite. A boa notícia é que a gengivite geralmente é reversível com uma boa rotina de higiene bucal. Tratar a gengivite (um estágio inicial da doença gengival) é tão fácil quanto contar até três: escovar os dentes, usar fio dental e fazer limpezas e check-ups profissionais. Em paralelo aos hábitos adequados, de escovar os dentes e usar fio dental, usar enxaguante bucal também pode ser eficaz na redução da gengivite. Fale 
com o seu dentista para mais informações, preocupações e para uma avaliação oral abrangente quando puder voltar às consultas para limpezas e check-ups regulares.

A placa bacteriana é composta por complexos bacterianos que vivem na boca e aderem aos dentes. Alguns tipos podem causar cárie e outros podem causar doença gengival. Para impedir a formação de placa bacteriana, certifique-se de usar fio dental para remover os germes e as partículas de comidas que ficam entre os dentes. Enxaguantes bucais também podem ser eficazes para reduzir a formação de placas bacterianas. Escove os dentes duas vezes ao dia por dois minutos com um creme dental fluoretado e não se esqueça de escovar a língua!

Se está preocupado com a formação de placa bacteriana, mas não pode ir ao dentista, existem algumas pastilhas e evidenciadores que você pode comprar para saber onde há placas nos seus dentes e na sua gengiva, certificando-se assim que as técnicas de remoção estejam funcionando efetivamente.

\section{O que caracteriza uma emergência odontológica durante a pandemia da COVID-19?}

De acordo com as orientações gerais da Associação Americana de Dentistas ( $A D A$, na sigla em inglês), uma emergência odontológica é aquela que potencialmente representa um risco à vida e que requer tratamento imediato para:

- Sangramento descontrolado

- Infeccção bacteriana que pode comprometer as vias respiratórias do paciente

- Trauma envolvendo ossos faciais, potencialmente comprometendo as vias respiratórias do paciente

Tratamento odontológico urgente são aquelas condições que requerem atenção imediata para aliviar a dor ou o risco de infecção. A ADA recomenda que os dentistas usem sua experiência profissional para determinar se um paciente necessita de algum cuidado urgente ou emergencial.

Nós entendemos que as diferentes respostas federais, estaduais e locais à atual pandemia da COVID-19 podem fazer com que as pessoas se sintam inseguras quanto ao que se caracteriza como atendimento odontológico urgente ou emergência odontológica. Aqui estão algumas situações em que você deve contatar o seu dentista imediatamente:

- Se um pedaço grande do dente ou o dente inteiro cair

- Há aparente dano no nervo, como uma sensação de dormência

- Você está com sinais de abcesso ou infecção (dor, inchação, quente ao toque e vermelhidão)

- Se suspeita que você ou outra pessoa está com a mandíbula quebrada

- Se você recentemente foi submetido a um tratamento de canal e está preocupado com o nível de dor, inchaço ou mal-estar

- Qualquer outro sintoma anormal

Zinco pode matar o vírus que causa a COVID-19? 
Não, o zinco não pode matar o vírus COVID-19. Vamos começar com o básico. O zinco é um mineral essencial, conhecido por suas propriedades antibacterianas e desempenha um papel crucial em nosso corpo, inclusive para manter o sistema imunológico saudável. Além disso, o zinco está naturalmente presente em nossas bocas e o zinco incluído na pasta de dente é seguro para uso.

No entanto, o uso de zinco para matar ou prevenir o vírus COVID-19 não foi analisado nem validado. A melhor maneira de ajudar a se proteger contra a COVID-19 é lavar as mãos, seguir as diretrizes do Centro de Controle e Preveção de Doenças dos EUA (CDC, na sigla em inglês) e praticar o distanciamento social 1,2,3,4

\section{OS AUTORES DECLARAM NÃO HAVER CONFLITOS DE INTERESSE}

\section{REFERÊNCIAS}

1. Colgate. Diaponivel em: https://www.colgate.com.br/oral-health/threats-to-dentalhealth/dental-care-during-coronavirus

2. Coelho Paraguassu, E. ., Chen, H. ., Zhou, F. ., Xu , Z. ., \& Wang, M. . (2020). Coronavirus and COVID-19: The latest news and views from the scientific community about the new coronavirus and COVID-19. Brazilian Journal of Implantology and Health Sciences , 2(3), 96-109. https://doi.org/10.36557/2674-8169.2020v2n3p96-109

3. Coelho Paraguassu, E. ., Celis de Cardenas, A. M. ., Ferreira de Andrade, R. ., La Vecchia, C. ., \& Naldi, L. . (2020). The Covid-19 explosion in the state of Amapá: how is the most preserved region in the Brazilian Amazon currently fighting the SARS-COV 2 pandemic?. Brazilian Journal of Implantology and Health Sciences, 2(5), 3-11. https://doi.org/10.36557/2674-8169.2020v2n5p3-11

4. Coelho Paraguassu, E. . (2020). COVID-19, a relação direta entre o capital, solidariedade e as vidas. Brazilian Journal of Implantology and Health Sciences , 2(3), 01-04. Recuperado de https://bjihs.emnuvens.com.br/bjihs/article/view/33 